\title{
Indices of body fat distribution for assessment of lipodysthrophy in people living with HIV/AIDS
}

\author{
Aline Francielle Mota Segatto ${ }^{1}$, Ismael Forte Freitas Junior ${ }^{2 *}$, Vanessa Ribeiro Dos Santos ${ }^{3}$, \\ Kelly Cristina de Lima Ramos Pinto Alves ${ }^{4}$, Dulce Aparecida Barbosa ${ }^{4}$, Alexandre Martins Portelinha Filho ${ }^{5}$ \\ and Henrique Luiz Monteiro ${ }^{6}$
}

\begin{abstract}
Background: Metabolic and morphological changes associated with excessive abdominal fat, after the introduction of Antiretroviral Therapy, increase the risk of cardiovascular disease in people living with HIV/AIDS(PLWHA). Accurate methods for body composition analysis are expensive and the use of anthropometric indices is an alternative. However the investigations about this subject in PLWHA are rare, making this research very important for clinical purpose and to advance scientific knowledge. The aim of this study is to correlate results of anthropometric indices of evaluation of body fat distribution with the results obtained by Dual-energy X-Ray Absorptiometry(DEXA), in people living with HIV/AIDS.
\end{abstract}

Methods: The sample was of 67 PLWHA(39 male and 28 female), aged $43.6 \pm 7.9$ years. Body mass index, conicity index, waist/hip ratio, waist/height ratio and waist/thigh were calculated. Separated by sex, each index/ratio was plotted in a scatter chart with linear regression fit and their respective Pearson correlation coefficients. Analyses were performed using Prism statistical program and significance was set at 5\%.

Results: The waist/height ratio presented the highest correlation coefficient, for both male $(r=0.80, p<0.001)$ and female $(r=0.87, p<001)$, while the lowest were in the waist/thigh also for both: male group $(r=0.58, p<0.001)$ and female group $(r=0.03, p=0.86)$. The other indices also showed significant positive correlation with DEXA.

Conclusion: Anthropometric indices, especially waist/height ratio may be a good alternative way to be used for evaluating the distribution of fat in the abdominal region of adults living with HIV/ADIS.

Keywords: AIDS/HIV, Abdominal obesity, Lipodysthrophy, Body composition

\section{Background}

With the onset of the treatment with antiretroviral therapy (HAART) in the 90s, there was a significant increase in survival and quality of life of people living with HIV/ AIDS (PLWHA), due to the action of this therapy in the fight against infectious and opportunist diseases [1]. However, pharmacological control of the disease has the side effect of altering body fat distribution, characterized by morphological changes (lipodystrophy) that result in excess fat in the central region of the body that increases the risk of cardiovascular diseases [2]. Despite some

\footnotetext{
* Correspondence: ismael@fct.unesp.br

${ }^{2}$ Departamento de Educação Física, Universidade Estadual PaulistaUNESP, Rua Roberto Simonsen, 305 Centro Educacional, Presidente Prudente, São Paulo CEP 19.060-900, Brasil

Full list of author information is available at the end of the article
}

patients without HAART treatment present lypodistrophy, most of studies indicate that lypodistrophy in those under HAART, are time-dependent $[3,4]$.

Methods of analysis of body composition such as Dual Energy X-Ray Absorptiometry (DEXA) and Computed Tomography are considered the accurate techniques for body composition assessment for PLWHA [5,6]. However, the acquisition of sophisticated equipments or even the individual cost of each exam has made it difficult the access to most population [7].

Given the difficult access to these techniques, it becomes primordial the use of procedures for the diagnosis of abdominal obesity in PLWHA. The anthropometric indices can be used as simple procedures to classify PLWHA on the risk of diseases related to excess central

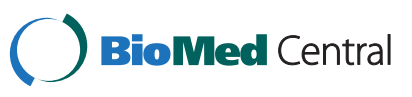


obesity, as they are widely used successfully for this purpose in non HIV-infected adult population [8].

However, investigations concerning the use of anthropometric indices to assess the risks related to excess fat in PLWHA are still scarce, and literature suggests that, for most methods of body composition assessment, the parameters assumed to be true for one population group may not be the same for others [9].

The objective of the present study is to correlate results of some anthropometric indices with values obtained by DEXA, in order to assess whether these indices can be used for diagnosis of excess central fat in people living with HIV/AIDS.

\section{Methods}

Cross-sectional descriptive study with people living with HIV/AIDS attended by Sexually Transmitted Diseases Center of São Paulo State (STDC) was conducted in the city of Presidente Prudente, São Paulo, Brazil. In 2009 there were a total of 653 patients attended in the STDC, which is a governmental health service that provides diagnostic and treatment of sexually transmitted diseases. Between May to July, a total of 286 patients, aged 18 or over, were attended and all of them were invited to participate in the present study. From this amount, 131 accepted to participate and attended all inclusion criteria of the present study.

The inclusion criteria were: (1) age 18 years or over; (2) to be patient of the Sexually Transmitted Diseases Center of São Paulo State, for, et least, one year; (2) to be treated with the antiretroviral therapy for, at least, one year. Those who made use of a pacemaker, antihyperlipidemic drugs, pregnant women and prisoners were not included.

Thus, the final sample was composed by 67 individuals aged $44.0 \pm 7.6$ years $(39$ male, $45.0 \pm 8.4$ years and 28 female, $42.0 \pm 6.3$ years).

Evaluations were performed by researches with experience in assessing body composition.at the Centro de Estudos e Laboratório de Avaliação e Prescrição de Atividades Motoras (CELAPAM) da Universidade Estadual Paulista "Julio de Mesquita Filho" FCT-Unesp Presidente Prudente.

\section{Procedures}

Body weight $(\mathrm{kg})$, height $(\mathrm{m})$ and waist, hip and thigh $(\mathrm{cm})$ circumferences were recorded to estimate the suggested indices.

The weight was measured on a digital electronic scale (Filizzola PL 150, Filizzola Ltda) to the nearest $0.1 \mathrm{~kg}$. Height was measured using a stadiometer to the nearest $0.1 \mathrm{~cm}$ and 2 meters extension. The subjects were wearing light clothing and without shoes. The waist, hip and thigh circumferences were performed using a metal measuring tape, Sanny, accurate to $0.1 \mathrm{~cm}$ and maximum length of $2 \mathrm{~m}$. The measurement of waist circumference was performed with the tape positioned at the smallest circumference between the iliac crest and last rib. The hip circumference was measured with the measuring tape positioned at the largest circumference at the gluteus maximus.

All anthropometric measurements followed procedures described by Lohman [10] and Freitas Jr. et al. [11] and were collected by trained staff.

\section{Dual Energy X-ray Absorptiometry (DEXA)}

Whole body composition was measured with a Lunar DPX-NT scanner (GE Medical, Software: Lunar DPX Encore 2007 version 11.40.004, Madison, WI).

All measurements were made at the CELAPAM with constantly controlled temperature. Each morning before any measurements were taken, the device was calibrated by the same researcher and, according to the reference values provided by the manufacturer, the tests presented high reliability.

The subjects were scanned wearing light clothing while lying flat on their back with arms by the side, without moving during the measurement. The equipment provided measurements of percentage of the trunk fat mass (visceral plus subcutaneous).

\section{Index and ratios}

The following indices and ratios were calculated:

Body Mass Index:

$$
\frac{\text { weight (kilos) }}{\text { height (meters) }}
$$

Conicity index: waist circumference (meters)

$$
0,109 \times \sqrt{\frac{\text { Body Weight }(\text { kilos })}{\text { Height }(\text { meters })}}
$$

Waist/hip ratio:

$$
\frac{\text { waist circumference (centimeters) }}{\text { hip circumference (centimeters) }}
$$

Waist/height ratio:

$$
\frac{\text { waist circumference (centimeters) }}{\text { height centimeters }}
$$

Waist/thigh ratio:

$$
\frac{\text { waist circumference (centimeters) }}{\text { thigh circumference (centimeters) }}
$$

The study was approved by the Ethics Committee on Human Experimentation of the Sao Paulo State 
University at Presidente Prudente. (protocol number 2101/08) and all research participants gave written informed consent after receiving a thorough explanation of the research project.

\section{Statisitical analysis}

For data analysis, the sample was divided by sex, whereas body composition is different between men and women.

The normality of the analyzed data was tested by the test of Komolgorov-Smirnov (K-S).

Mean, standard deviation and the Pearson productmoment correlation coefficient( $\mathrm{r}$ ) were calculated in SPSS version 13.00 (SPSS Inc., Chicago, IL).

The sample was split by sex and each index/ratio was plotted in the scatter plot with linear regression. In the presentation of each figure the values of correlation and their significance have been described. The graphics were performed in the statistical program Prism and the Statistical significance (p) was set at $5 \%$.

\section{Results}

The general characteristics of the sample are described in Table 1.

In the results of Table 2 can be observed that all variables presented significantly correlation between index/ ratios with trunk fat mass estimated by DEXA, except the waist/height ratio in the female group. In Figure 1, individual data for each correlation, for both sexes, can be better visualized.

\section{Discussion}

The introduction of drugs against HIV is considered a milestone in the history of the disease, because it increased, significantly, survival and quality of life of people living with

Table 1 Mean values and standard deviation of anthropometric variables according to sex

\begin{tabular}{lcc}
\hline Variables & Male & Female \\
\hline Age (years) & $44.7 \pm 8.4$ & $42.3 \pm 7.3$ \\
Weight $(\mathrm{Kg})$ & $71.6 \pm 13.74$ & $63.6 \pm 12.4$ \\
Height $(\mathrm{cm})$ & $170.9 \pm 7.34$ & $159.0 \pm 5.64$ \\
Waist Circumference $(\mathrm{cm})$ & $88.9 \pm 12.75$ & $82.6 \pm 12.25$ \\
Thigh Circumference $(\mathrm{cm})$ & $48.4 \pm 4.30$ & $51.5 \pm 8.19$ \\
Hip Circumference $(\mathrm{cm})$ & $94.4 \pm 8.38$ & $97.4 \pm 10.37$ \\
Trunk length $(\mathrm{cm})$ & $90.4 \pm 3.48$ & $84.8 \pm 2.59$ \\
Body mass index $\left(\mathrm{Kg} / \mathrm{m}{ }^{2}\right)$ & $23.5 \pm 4.62$ & $23.8 \pm 5.63$ \\
Conicity index $(\mathrm{cm} / \mathrm{Kg} / \mathrm{m})$ & $1.3 \pm 0.09$ & $1.2 \pm 0.07$ \\
Waist hip ratio $(\mathrm{cm} / \mathrm{cm})$ & $0.9 \pm 0.08$ & $0.9 \pm 0.09$ \\
Waist estature $\mathrm{ratio}(\mathrm{cm} / \mathrm{cm})$ & $0.5 \pm 0.08$ & $0.5 \pm 0.07$ \\
Waist thigh ratio $(\mathrm{cm} / \mathrm{cm})$ & $1.8 \pm 0.20$ & $1.6 \pm 0.32$ \\
Trunk fat mass $(\mathrm{kg})$ & $11.3 \pm 5.4$ & $10.0 \pm 5.5$ \\
\hline
\end{tabular}

Table 2 Mean values, standard deviation and correlation coefficient between indices/ratios with trunk fat mass estimated by DEXA

\begin{tabular}{|c|c|c|c|c|}
\hline Variables & Sex & Mean \pm SD & $r$ & $p$ \\
\hline \multirow[t]{2}{*}{ Body mass índex $\left(\mathrm{Kg} / \mathrm{m}^{2}\right)$} & $M$ & $23.46 \pm 4.62$ & 0.77 & 0.000 \\
\hline & $\mathrm{F}$ & $23.83 \pm 5.63$ & 0.67 & 0.000 \\
\hline \multirow[t]{2}{*}{ Conicity index (cm/Kg/m) } & M & $1.26 \pm 0.08$ & 0.52 & 0.000 \\
\hline & $\mathrm{F}$ & $1.20 \pm 0.06$ & 0.58 & 0.000 \\
\hline \multirow[t]{2}{*}{ Waist/hip ratio (cm/cm) } & M & $0.94 \pm 0.07$ & 0.60 & 0.000 \\
\hline & $\mathrm{F}$ & $0.85 \pm 0.09$ & 0.52 & 0.004 \\
\hline \multirow[t]{2}{*}{ Waist/ height ratio $(\mathrm{cm} / \mathrm{cm})$} & $M$ & $0.52 \pm 0.08$ & 0.80 & 0.000 \\
\hline & $F$ & $0.52 \pm 0.06$ & 0.87 & 0.000 \\
\hline \multirow[t]{2}{*}{ Waist/thigh ratio $(\mathrm{cm} / \mathrm{cm})$} & $M$ & $1.83 \pm 0.19$ & 0.58 & 0.000 \\
\hline & $F$ & $1.63 \pm 0.32$ & 0.03 & 0.859 \\
\hline \multirow[t]{2}{*}{ Trunk fat mass (kg) } & M & $10.39 \pm 5.96$ & - & - \\
\hline & $\mathrm{F}$ & $10.90 \pm 4.58$ & - & - \\
\hline
\end{tabular}

$\mathrm{M}=$ male, $\mathrm{F}=$ female, $\mathrm{SD}=$ Standard Deviation.

HIV/AIDS [12-14]. Despite the benefits with the treatment, side effects, as lipodystrophy, deserve attention due to health damages [15].

The present study investigated the correlation between anthropometric indices and the trunk fat mass measured by a more accurate technique.

National $[16,17]$ and international $[18,19]$ studies make use of indices to classify the nutritional status or to relate excess weight and cardiovascular risk, but little is investigated about the use of such methods in PLWHA.

Despite being a body fat indicator more related to total body fat than to the central fat, and be limited to indicate body fat with risk cardiovascular risk $[20,21]$, the body mass index (BMI), in the present study, showed high correlation with the trunk fat mass in both sexes.

The high correlation between BMI and total body mass observed in healthy adults [22,23], is one of the limitations that do not allow differentiating excess weight caused by fat or lean fat mass $[24,25]$. However, the specificity of the body composition of the investigated group, as the excessive accumulation of fat in the trunk region, known as lipohypertrophy or the little amount of fat in the limb areas, known as lipoatrophy $[26,27]$, should be responsible for the high rates of correlation between BMI and trunk fat mass. No similar studies were found that can permit a deep discussion of the results.

From the studies found in the literature, that used the other body indices to evaluate excess of central fat in PLWHA, only two $[3,28]$ used waist/hip ratio.

The waist/hip ratio results in this study corroborate the findings of Florindo et al. [3] and Padilla et al. [28] in studies performed in adult PLWHA, Spanish and Brazilian, respectively. They also found a positive correlation between 


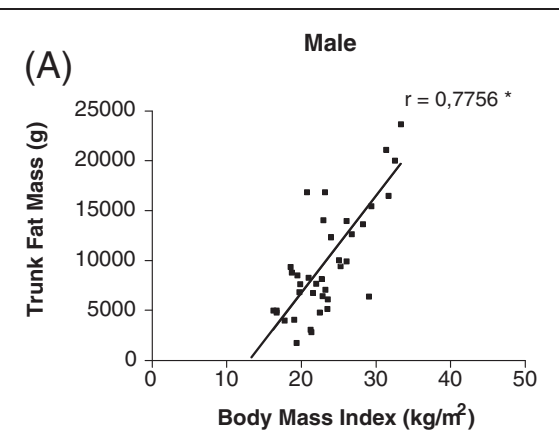

(C)

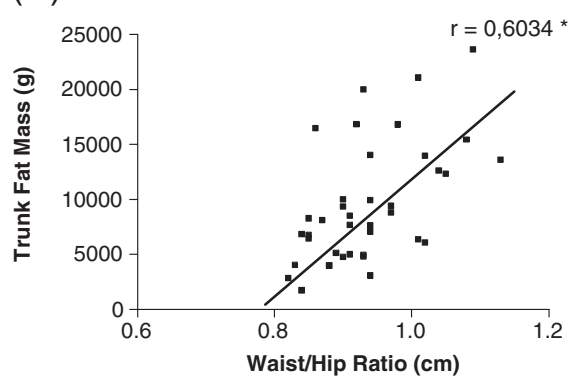

(E)

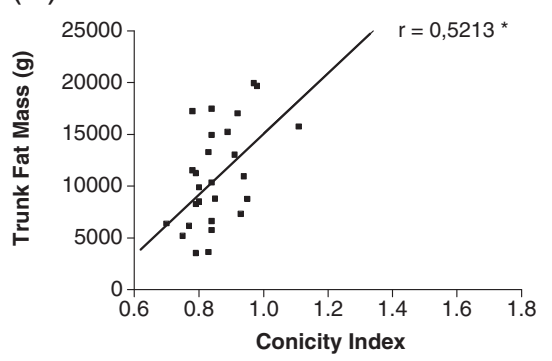

(G)

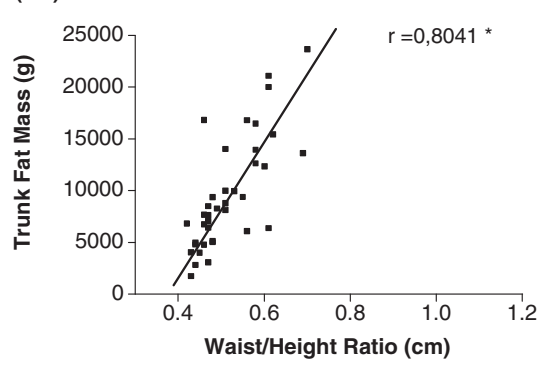

(I)

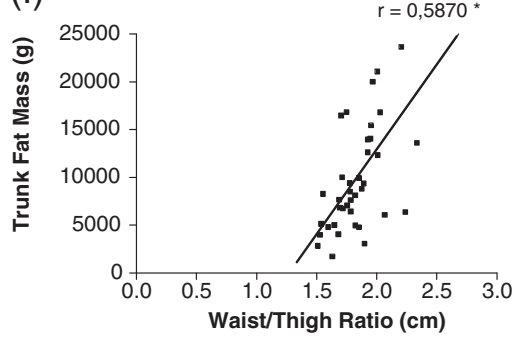

(B) Female

(B) $\quad r=0.6751^{*}$

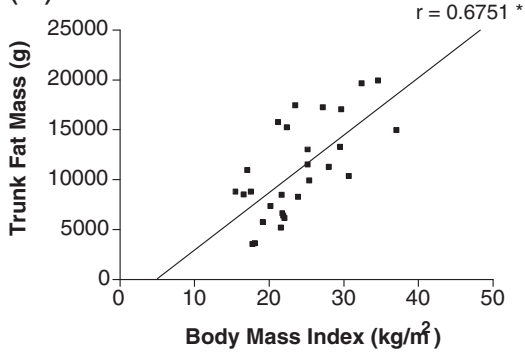

(D)

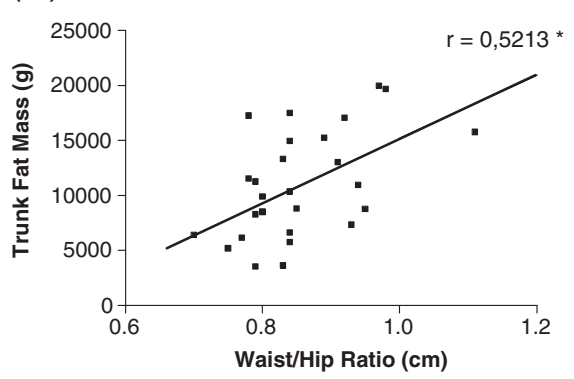

(F)

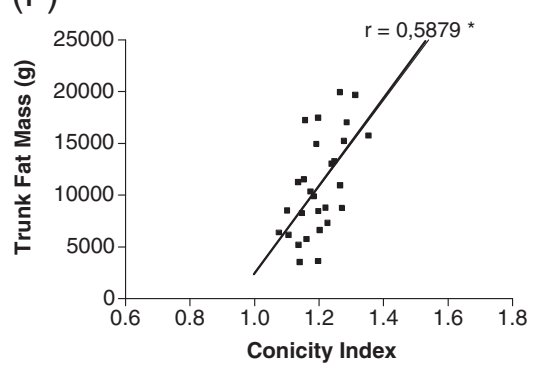

(H)

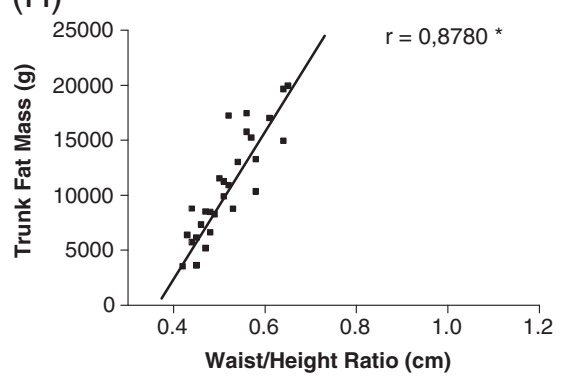

(J)

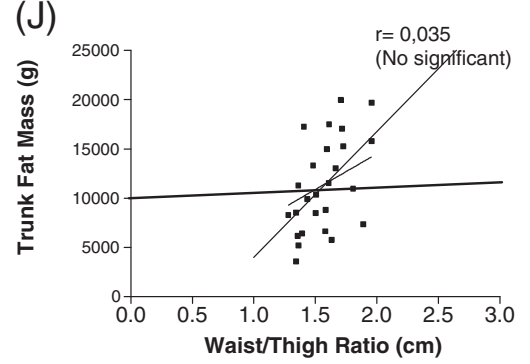

Figure 1 Scatterplots comparing values of trunk fat mass (grams) and its Indices / Ratio for sex. (Attached separately). 
waist/hip ratio with abdominal fat estimated by gold standard equipment (computed tomography). These authors inferred that, this may be a good method to estimate abdominal fat in PLWHA.

The waist/thigh ratio (WTR) was proposed as an alternative to waist/hip ratio (WHR) to estimate body fat distribution and the prediction of morbidities, by using the circumference of the thigh, which is unaffected by variations in the pelvic architecture, like happens with the hip [29]. However, in this study, the highest correlation values were observed between WHR and DEXA, while the WTR showed no significant correlation for females. Similar results were also observed by Vasques et al. [30], who studied non infected adult subjects. It is possible that, the low correlation values of WTR are results of lipohypertrophy, lipoatrophy or both, resulting in variations in the morphological distribution of body fat and reflect on the WTR. Our results suggest that this index needs to be further studied for use as a risk factor in PLWHA.

The conicity index is based on the proposition that people who accumulate fat in the abdominal area have a body shape like a double cone, two cones with common base, arranged one over the other [31]. In the present investigation, the conicity index showed a better correlation with DEXA value than the WTR for females. According to Guedes and Guedes [32] the main advantage of the conicity index compared with WTR is to present higher sensitivity for analysis of body fat distribution in non infected subjects, considering the probable joint variation of the measures of waist and hip circumference.

The index that presented the highest correlation with trunk body fat measured by DEXA was a waist/height ratio (WHeR), with $\mathrm{r}=0.80$ for males and 0.87 for females. Lin et al. [33] studied non infected adult individuals and obtained results consistent with our study and found strong association with excess of abdominal fat and with several cardiovascular risk factors. The advantage in applying this indicator is related to the adjustment for height that might facilitate direct comparisons between different populations [34]. For PLWHA, another positive aspect to this technique is that its ratio use only of the height and waist variables, focusing thus in the central fat distribution that relates to cardiac risk factors, without suffering the influence of variables of body composition in peripheral segments of the body that can be altered by the lipodystrophy syndrome and, thus, interfere the results.

Despite the importance of the findings of this study, some limitations should be mentioned, like the fact that the period of time that the subjects were infected with the virus was not investigated and also did not provide information about the presence or absence of limb lipoatrophy and trunk lipohypertrophy.

Despite the significant results found in the present study, some limitations need to be stated. The two main limitations are that, the small sample size limit the extrapolation of the results and the cross sectional study do not permit to establish a cause-effect effect of the all index/ratio and cardiovascular risk in PLWHA.

\section{Conclusions}

In conclusion, our results suggest that, the use of anthropometric indices can be useful for assessing central fat distribution of PLWHA for research purpose and in monitoring health services that do not have more accurate and sophisticated equipment to assess body fat distribution. However, the choice of the method should be careful and further studies are necessary to confirm our results.

\section{Competing interests}

The authors declare that they have no competing interests.

\section{Authors' contributions}

AFMS: Main mentor and responsible for DEXA assessment of patients, organization of the data and redaction of the methods of the manuscript. IFFJ: supervisor of the manuscript and responsible for the statistical analysis. VRS: Responsible for anthropometrical and DEXA assessment of patients, organization of the data and redaction of the methods of the manuscript. KCLRPA: Responsible for contacting the patients, collection of blood samples, and participated in the discussion of the manuscript. DAB: Responsible for supervising the data collection, interpretation of the results and redaction of the manuscript. AMPF: Responsible for the clinical assessment of the patients and interpretation of the results. HLM: Responsible for the statistical analysis and had a substantial contribution in the discussion of the results of the manuscript. All authors read and approved the final manuscript.

\section{Author details}

${ }^{1}$ Department of Physiotherapy, Univ. Estadual Paulista, Campus of Presidente Prudente, São Paulo, Brazil. ${ }^{2}$ Departamento de Educação Física, Universidade Estadual PaulistaUNESP, Rua Roberto Simonsen, 305 Centro Educacional, Presidente Prudente, São Paulo CEP 19.060-900, Brasil. ${ }^{3}$ Physical Education, Univ. Estadual Paulista, Campus of Rio Claro, São Paulo, Brazil. ${ }^{4}$ Department of Nursing, São Paulo Federal University, São Paulo, Brazil. ${ }^{5}$ Sexually Transmitted Diseases Center of São Paulo State, Presidente Prudente, São Paulo, Brazil. 'Department of Physical Education, Univ. Estadual Paulista, Campus of Bauru, São Paulo, Brazil.

Received: 31 August 2011 Accepted: 22 September 2012 Published: 2 October 2012

\section{References}

1. Liu C, Johnson L, Ostrow D, Silvestre A, Visscher B, Jacobson LP: Predictors for lower quality of life in the HAART era among HIVinfected men. J Acquir Immune Defic Syndr. 2006, 42(4):470-77.

2. Scevola D, Di Matteo A, Lanzarini P, Uberti F, Scevola S, Bernini V, Spoladore $G$, Faga A: Effect of exercise and strength training on cardiovascular status in HIV-infected patients receiving highly active antiretroviral therapy. Aids. 2003, 17(1):123-29.

3. Guarald G, Murri R, Orlando G, Orlandi E, Sterrantino G, Borderi M, Grosso C, Cattelan AM, Nardini G, Beghetto B, Antinori A, Espósito R, Wu AW: Morphologic alterations in HIV- infected people with lipodystrophy are associated with good adherence to HAART. HIV clin trials. 2003, 4(2):99-106.

4. Guimarães MMM, Greco DB, de Ribeiro A, Penido MG, Machado LJC: Distribuição da gordura corporal e perfis lipídico e glicêmico de pacientes infectados pelo HIV. Arq Brás Endocrinol Metab. 2007, 51(1):42-51.

5. Florindo AA, Latorre MRDO, Santos ECD, Borelli A, Rocha MS, Segurado AAC: Validation of methods for estimating HIV/AIDS patients body fat. Rev Saude Publica. 2004, 38(5):643-49.

6. Carr A, Cooper DA: Adverse effects of antirretroviral therapy. Lancet 2000, 356(9239):1423-30. 
7. Freedman DS, Khan LK, Serdula MK, Dietz WH, Srinivasan SR, Berenson GS: Inter-relationships among childhood BMI childhood height and adult obesity: the Bogalusa Heart Study. Int J Obes. 2004, 28(1):10-6.

8. Aronne L: Classification of obesity and Assessment of Obesity-Related Health Risks. Obesity Research. 2002, 10(2):105-115.

9. Norgan NG: Body mass index and body energy stores in developing countries. Eur. J. din. Nutr. 1990, 44(1):79-84

10. Lohman TG: Advances in body composition: current issues in exercise science series. Monograph n.3. Champaign: Human Kinetics; 1992.

11. Freitas IF Jr, Bueno DR, Silva CB, Codogno JS, Conterato I, Fernandes RA, Fragoso Neto RA, Messias K, Rosa CSC: Padronização de técnicas antropométricas. São Paulo: Cultura Acadêmica: Universidade Estadual Paulista, Pró reitoria de graduação; 2009.

12. Palella FJ, Delaney KM, Moorman AC, Loveless MO, Fuhrer J, Satten GA, Aschman DJ, Holmberg SD: Declining Morbidity and mortality among patients with advanced humab immunodeficiency vírus infection. $N$ Engl J Med 1998, 338(13):858-60.

13. Crum NC, Riffenburgh RH, Wegner S, Agan BK, Tasker SA, Spooner KM, et al: Comparisons of causes of death and mortality rates among HIV-infected persons. Analysis of the Pre-, early, and late HAART (highly active antiretroviral therapy) eras. J Acquir Immune Defic Syndr 2006, 41(2):194-200.

14. Nash D, Katyal M, Brinkhof MW, Keiser O, May M, Hughes R, et al: Long-term immunologic response to antiretroviral therapy in low-income countries: a collaborative analysis of rospective studies. AIDS 2008, 22(17):291-302.

15. Mutimura E, Crowther NJ, Cadê TW, Yarasheski KE, Stewart A: Exercise training reduces central adipodity and improves metabolic índices in HAART-treated HIV-positive subjects in Rwanda: a randomized controlled trial. AIDS Res Hum Retroviruses 2008, 24(1):15-23.

16. Guimarães MMM, Greco DB, Ribeiro AOJ, Penido MG, Machado LJC: Distribuição da gordura corporal e perfis lipídico e glicêmico de pacientes infectados pelo HIV. Arq Bras Endocrinol Metab 2007, 51(1):42-51.

17. Gus M, Moreira LB, Pimentel M, Gleisener ALM, Moraes RS, Fuchs F, Fuchs FD: Associação entre diferentes indicadores de obesidade e prevalência de hipertensão arterial. Arq Bras Cardiol 1998, 70(2):111-114.

18. Mallon PWG, Miller J, Cooper DA, Carr A: Prospective evaluation of the effects of antiretroviral therapy on body composition in HIV-1-infected men starting therapy. AIDS 2003, 17(7):971-979.

19. Engelson ES, Agin D, Kenya S, Werber-Zion G, Luty B, Albu JB, Kotler DP: Body composition and metabolic effects of a diet and exercise weight loss regimen on obese, HIV-infected women. Metab Clin Exp 2006, 55(10):1327-1336.

20. Glaner MF: Índice de massa corporal como indicativo da gordura corporal comparado às dobras cutâneas. Rev Bras Med Esporte 2005, 11(4):243-246.

21. Khongsdier R: BMI and morbidity in relation to body composition: a cross-sectional study of a rural community in North-East India. Br J Nutr 2005, 93(1):101-107

22. World Health Organization: Obesity. Preventing and managing the global epidemic. Geneva: World Health Organization; 1998. Report of WHO Consultation on Obesity.

23. Monteiro CA: Epidemiologia da obesidade. In Obesidade. Edited by Halpern A, Matos AFG, Suplicy HL, Mancini MC, Zanella MT, organizadores. São Paulo: Lemos Editorial; 1998:15-30.

24. Allison DB, Faith MS, Heo M, Kotler DP: Hypothesis concerning the Ushaped relation between body mass index and mortality. Am J Epidemiol 1997, 146(4):339-49.

25. Landi F, Onder G, Gambassi G, Pedone C, Carbonin P, Bernabei R: Body mass index and mortality among hospitalized patients. Arch Intern Med 2000, 160(17):2641-2644

26. Diehl LA, Dias JR, Paes ACS, Thomazini MC, Garcia LR, Cinagawa E, Wiechmann SL, Carrilho AJF: Prevalência da Lipodistrofia Associada ao HIV em Pacientes Ambulatoriais Brasileiros: Relação com Síndrome Metabólica e Fatores de Risco Cardiovascular. Arq Bras Endrocrinol Metab 2008, 52(4):658-667.

27. Grinspoon S, Carr A: Cardiovascular risk and body-fat abnormalities in HIV-infected patients. N Engl J Med 2005, 352(1):48-62.

28. Padilla S, Gallego JA, Masia M, Ardoy F, Hernandez I, Gutierrez F: Ultrasonography and anthropometry for measuring regional body Fat in HIV-infected patients. Curr HIV Res 2007, 5(5):459-466.

29. Kahn HS: Alternative anthropometric measures of risk: possible improvements on the waist-hip ratio. In Progress in obesity research. 9a edth edition. Edited by Medeiros-Neto G, Halpern A, Bouchard C. London: John Libbey Eurotext Ltd; 2003:639-43.

30. Vasques ACJ, Rosado LEFPL, Rosado GP, Ribeiro RCL, Franceschini SCC, Priore SE, Geloneze B, Oliveira DR: Indicadores do perfil lipídico plasmático relacionados à resistência à insulina. Rev Assoc Med Bras 2009, 55(3):342-346.

31. Pitanga FJG, Lessa I: Indicadores antropométricos de obesidade como instrumento de triagem para risco coronariano elevado em adultos na Cidade de Salvador - Hahia. Arquivos Brasileiros de Cardiologia 2005, 85(1):26-31.

32. Guedes DP: Recursos Antropométricos para análise da composição corporal. Revista brasileira de Educação Física, São Paulo. 2006, 20(5):115-119.

33. Lin WY, Lee LT, Chen CY, Lo H, Hsia HH, et al: Optimal cut-off values for obesity: using simple anthropometric indices to predict cardiovascular risk factors in Taiwan. Int J Obes Relat Metab Disord 2002, 26(9):1232-1238.

34. Ho SY, Lam TH, Janus ED: Waist to stature ratio is more strongly associated with cardiovascular risk factors than other simple anthropometric indices. Ann Epidemiol 2003, 13(10):683-691.

doi:10.1186/1756-0500-5-543

Cite this article as: Segatto et al.: Indices of body fat distribution for assessment of lipodysthrophy in people living with HIV/AIDS. BMC Research Notes 2012 5:543.

\section{Submit your next manuscript to BioMed Central and take full advantage of:}

- Convenient online submission

- Thorough peer review

- No space constraints or color figure charges

- Immediate publication on acceptance

- Inclusion in PubMed, CAS, Scopus and Google Scholar

- Research which is freely available for redistribution

Submit your manuscript at www.biomedcentral.com/submit
C) Biomed Central 